\title{
An International Perspective on the Recent Behavior of Inflation
}

\author{
Silvio Contessi, Pierangelo De Pace, and Li Li
}

Several commentators have been concerned about the possibility that the euro area may be experiencing disinflation with the risk of deflation. However, the euro area is not the only economy navigating the risky waters of low inflation. Several other advanced economies have recently experienced below-target inflation as well as outright deflation. In this article, the authors collect data for nine advanced economies and document several facts about the behavior of inflation during the 2002-14 period. First, they show that the relationship between inflation rates and short-term rates displays similar changes across advanced economies - with and without central bank programs designed to increase the size of their balance sheets (e.g., large-scale asset purchases). Second, they describe recent indications that headline and core inflation are below target for individual countries. They then discuss various explanations for this trend (global factors, output gaps, and changes in inflation expectations), showing that there is some important heterogeneity across countries. Finally, they show that while output has become even more synchronized across countries since 2008, the cross-country correlation of inflation is no longer higher than the cross-country correlation of output. (JEL E31, E43, F42, F44)

Federal Reserve Bank of St. Louis Review, Third Quarter 2014, 96(3), pp. 267-94.

\footnotetext{
Silvio Contessi is an economist and Li Li is a graduate student at Harvard University and a former senior research associate at the Federal Reserve Bank of St. Louis. Pierangelo De Pace is an assistant professor at Pomona College. The authors thank David Andolfatto, Riccardo Di Cecio, Johanna Francis, and Yi Wen for useful comments and conversations.

( ) 2014, The Federal Reserve Bank of St. Louis. The views expressed in this article are those of the author(s) and do not necessarily reflect the views of the Federal Reserve System, the Board of Governors, or the regional Federal Reserve Banks. Articles may be reprinted, reproduced, published, distributed, displayed, and transmitted in their entirety if copyright notice, author name(s), and full citation are included. Abstracts, synopses, and other derivative works may be made only with prior written permission of the Federal Reserve Bank of St. Louis.
} 


\section{Contessi, De Pace, Li}

LSAP programs (Canada, Denmark, and Norway). We then document several facts about the behavior of inflation during the 2002:01-2014:04 period. ${ }^{1}$ First, we show informally that the relationship between inflation rates and short-term interest rates displays similar changes across advanced economies with and without large LSAP programs. Second, we document that headline and core inflation have recently been below inflation targets in all nine countries. However, observing inflation and price levels from a medium-term perspective reveals some important heterogeneity; very few countries are far from their medium-run objective. We discuss various explanations for this phenomenon: global shocks, economic slack, and changing inflation expectations. Among the large economies, the recent behavior of inflation suggests different trends and explanations. Finally, we show that the cross-country correlation of inflation is no longer higher than the cross-country correlation of output.

\section{THE MONETARY POLICY FRAMEWORK OF NINE ADVANCED ECONOMIES}

A large body of research has examined recent changes in monetary policy in advanced economies (see, for example, Bullard, 2010; Fawley and Neely, 2014; and Thornton, 2014). Here we provide a synthetic description of the monetary policy framework and stance in the nine economies studied. In most figures, the top panel represents the three large economies (the euro area, Japan, and the United States), all of which have implemented (or are still implementing) some form of LSAP program, as measured by a large expansion of the central bank's balance sheet. The middle panel represents the three small open economies (Sweden, Switzerland, and the United Kingdom) that have implemented or had implemented some form of LSAP program. The bottom panel represents the three small open economies (Canada, Denmark, and Norway) without LSAP programs.

Table 1 summarizes the historical and current inflation targets and the monetary policy instrument. Figure 1 plots the monetary policy rates of the nine economies and the asset sizes of their respective central bank balance sheets divided by nominal gross domestic product (GDP); this provides a sense of the magnitude of the unconventional monetary policy. Generally speaking, at the time this article was written, policy rates for most countries were at or close to the zero lower bound and had been there for a few years. In six of the economies, different LSAPs have been used in combination with extremely accommodative policy rates. Seven of these countries use forward guidance, as discussed below.

\section{Inflation Targeting}

Inflation targets are implemented in about 30 countries in various formats. Hammond (2012) provides an excellent review of the main modalities and country experiences. Hatcher and Minford (2013) survey recent strands of the literature to compare inflation targeting and price-level targeting as macroeconomic stabilization policies. As Hammond (2012, p. 5) explains,

Inflation targeting is a framework rather than a rigid set of rules for monetary policy. Nonetheless there are a number of essential elements of an inflation-targeting regime: 
Contessi, De Pace, Li

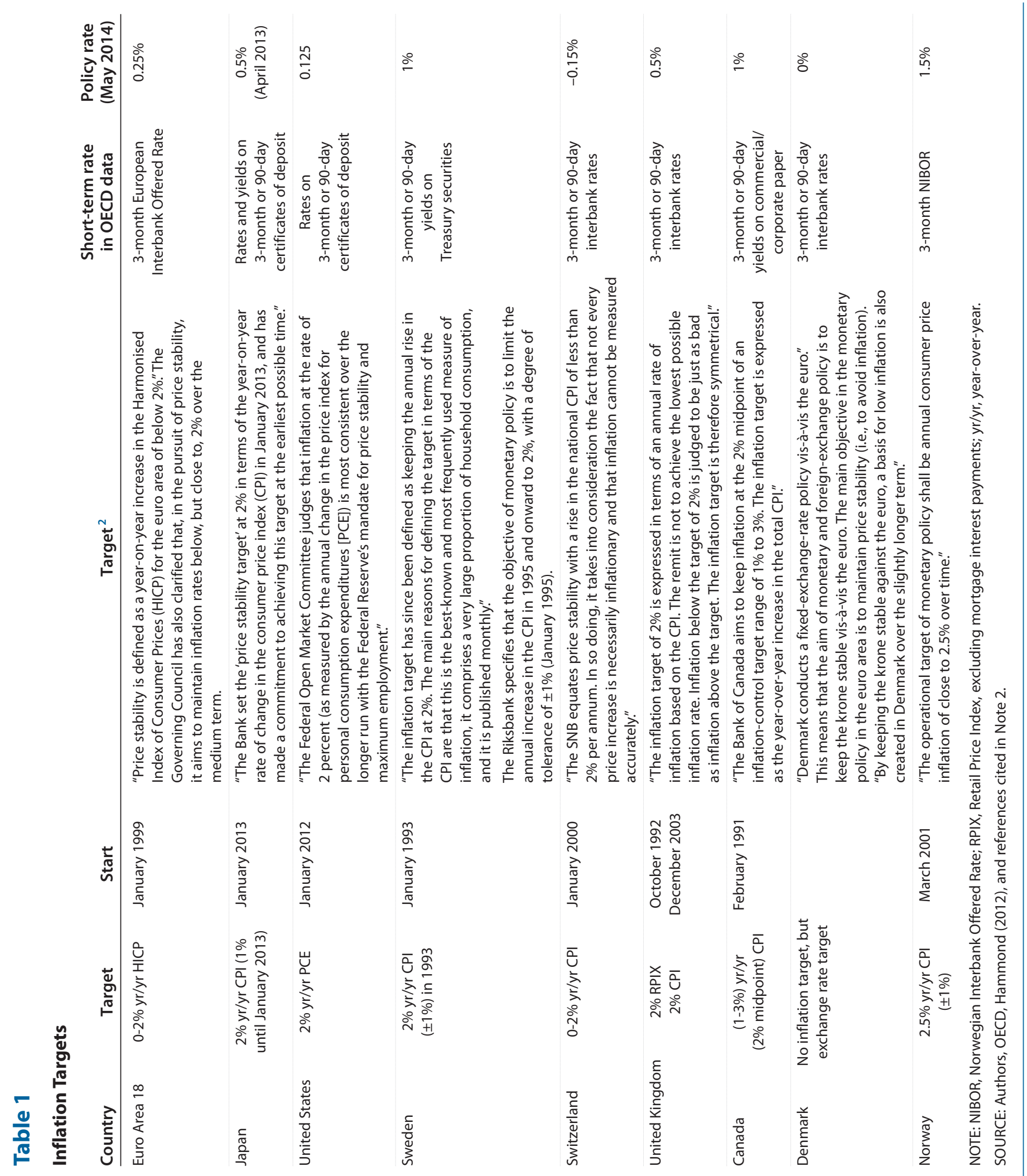




\section{Figure 1}

\section{Asset-to-GDP Ratio and Policy Rates by Country (1995:01-2014:05)}
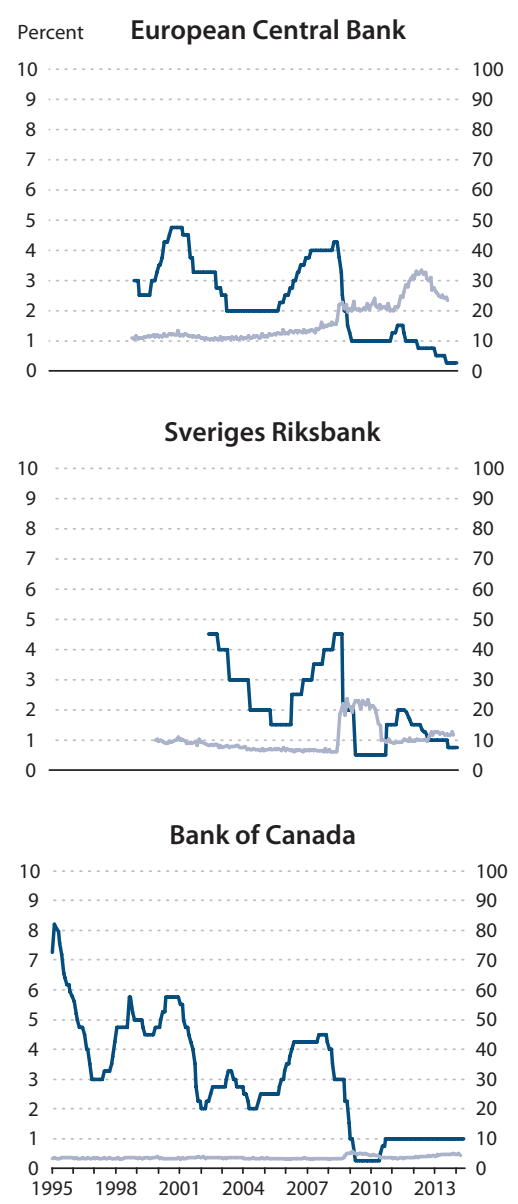

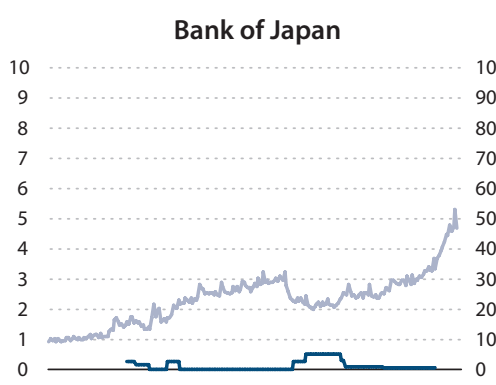

Swiss National Bank

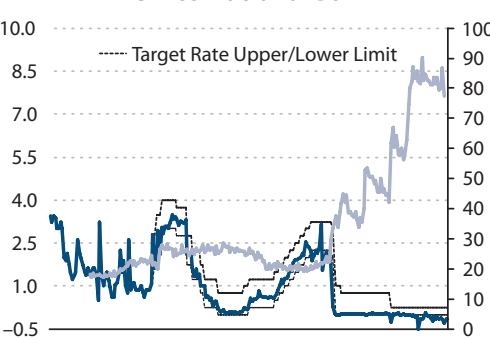

Danmarks Nationalbank

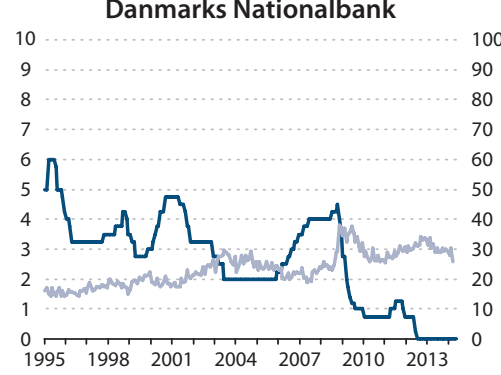

Federal Reserve

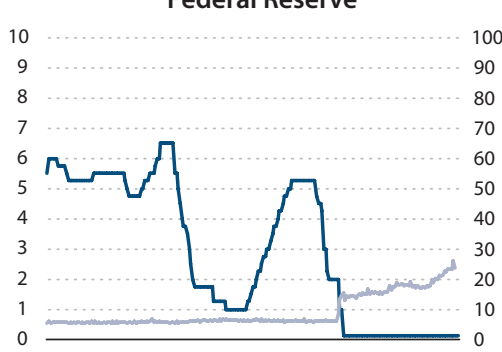

Bank of England

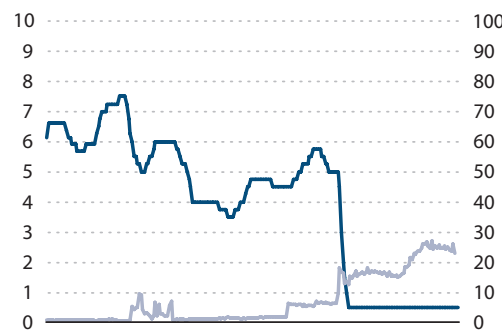

Norges Bank

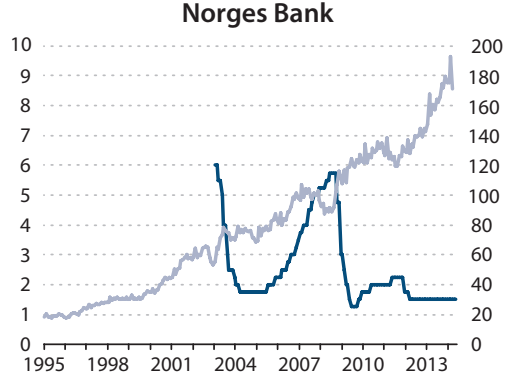

- Central Bank Rate (left axis) - Central Bank Asset-to-GDP Ratio (right axis)

NOTE: The last observation for the central bank rate is May 2014; the last observation for the central bank asset-to-GDP ratio is March 2014. SOURCE: National central banks and authors' calculations.

(i) Price stability is explicitly recognised as the main goal of monetary policy.

(ii) There is a public announcement of a quantitative target for inflation.

(iii) Monetary policy is based on a wide set of information, including an inflation forecast.

(iv) Transparency.

(v) Accountability mechanisms.

In most of the countries on which we focus, the inflation target is currently typically set at 2 percent of the year-over-year increase in the consumer price index (CPI), with some exceptions and qualifications as follows: 
- The European Central Bank (ECB) aims at inflation rates of below, but close to, 2 percent over the medium term clarified by the Governing Council of the ECB.

- In the United States, the target is 2 percent of the year-over-year increase in the personal expenditure chain-type price index, with an emphasis on core inflation.

- In Japan, the inflation target was moved from 1 percent to 2 percent in January $2013 .^{3}$

- In Switzerland, the target is 2 percent CPI inflation or below.

- In Norway, the target is 2.5 percent CPI inflation.

- Denmark targets the exchange rate stability with respect to the euro.

- Canada targets a 1 to 3 percent band centered on a 2 percent CPI inflation rate.

Figure 2 shows the deviation from the target of headline and core inflation rates for the nine advanced economies in June 2013, December 2013, and June 2014. We set the target at 2 percent except for Norway (2.5 percent) and attribute to Denmark the same target as the euro area because this country targets exchange rate stability with respect to the euro. Essentially all countries have recently been below their targets for both core and headline inflation. Sweden and Switzerland are experiencing moderate deflation.

Figure 3 shows the path of the price level since June 2009 with a focus on the months since January 2012 in the top-left inset boxes. We plot lines and bands for the price level consistent with target inflation rates from June 2009 forward in each of the panels; the exceptions apply to the United States, which started its inflation target in January 2012, and Japan, which started its 2 percent inflation target in January 2013. June 2009 represents the end of the U.S. recession according to the dating by the National Bureau of Economic Research. The U.S. panel also clearly shows the lower inflation rates associated with a slower-growing price level in 2013 and early 2014. The panel shows that the price-level path (solid black line) is quite heterogeneous across countries: Most economies are relatively close to the price level consistent with their inflation targets over the medium and long term (red dotted lines or dotted bands, depending on how the inflation target is specified), even if they have experienced relatively low inflation (solid blue line) in the very recent past (the past 18 months or so). For example, examining inflation and the price level for the euro area over these past five years does not prompt the same worries as examining them over the past two years. Clearly, if one projects lower inflation for the upcoming months or year, then the euro area may appear to be at risk of deflationary pressures. Japan is an important exception because it shows an upward movement beginning in December 2012.

\section{Forward Guidance}

The central banks of several of these countries have adopted forward guidance-that is, they communicate to the public the stance of monetary policy expected to prevail in the future (see Contessi and Li, 2013a,b, for a discussion of the main elements of forward guidance in advanced economies; also see Board of Governors of the Federal Reserve System, 2014, for the United States). It is widely understood that expectations play an important role in the economy and affect a variety of decisions, such as consumption, saving, and investment. Managing expectations is an important channel a central bank can use to achieve its policy 


\section{Figure 2}

\section{Differences Between the Target Inflation Rate and Actual Headline and Core Inflation Rates in June 2013, December 2013, and June 2014 for Nine Advanced Economies}
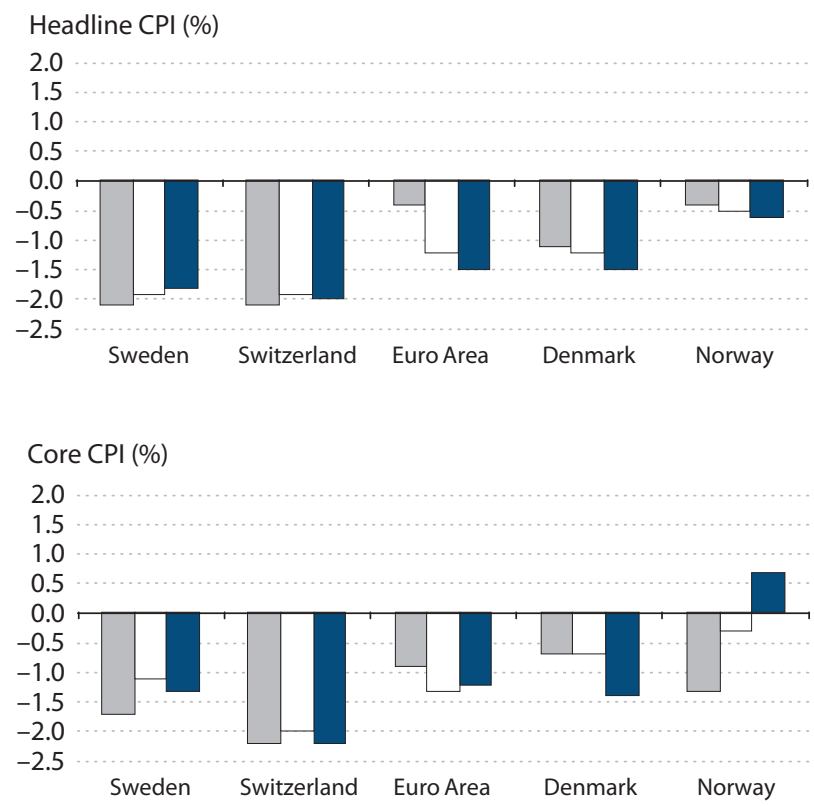

$\square$ 2013:06
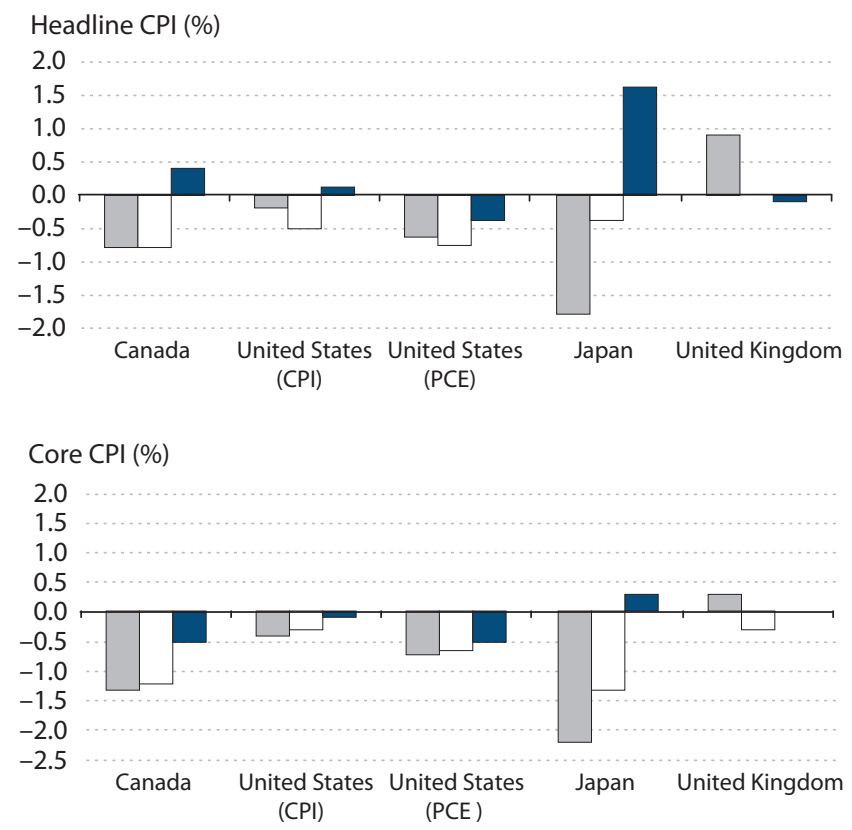

$\square$ 2013:12 $\quad$ 2014:06

NOTE: Sweden, Switzerland, Japan, Canada, and the United Kingdom set the inflation target at 2 percent in terms of the year-over-year rate of change in the headline CPI. The euro area set the inflation target at 2 percent in terms of the year-over-year rate of change in the headline HICP. The United States set the inflation target at 2 percent in terms of the year-over-year rate of change in the headline personal consumption expenditures (PCE). Norway set the inflation target at 2.5 percent in terms of the year-over-year target of change in the headline CPI. Denmark does not have an explicit inflation target but targets the nominal exchange rate with the euro.

SOURCE: Eurostat, Bureau of Economic Analysis, Statistics Bureau of Japan, Office for National Statistics, Statistics Canada, and authors' calculations.

objectives. In normal times, when the policy rate is not near zero, monetary policy authorities set policy instruments in response to economic fluctuations. Several models support the notion that a clear, easily understood policy rule can help successfully guide private sector expectations and ultimately may influence the economy consistent with the central bank's objectives. While the full-blown adoption of forward guidance in the United States was concurrent with the financial crisis and the zero lower bound, when further stimulus in the form of lower longterm yields was sought, the Federal Reserve and other central banks also experimented with forward guidance or practiced it to some extent when the policy rate was well above its zero lower bound. These two different environments (policy rates not near zero and policy rates near zero) tend to correspond to two different approaches to managing expectations. In the first case, the central bank simply forecasts and communicates to the public the economic outlook and the expected monetary policy action consistent with this outlook but does not commit to a specific policy action. The monetary policy stance could change in response to 


\section{Figure 3}

\section{Price Level by Country (2009:06-2014:04)}
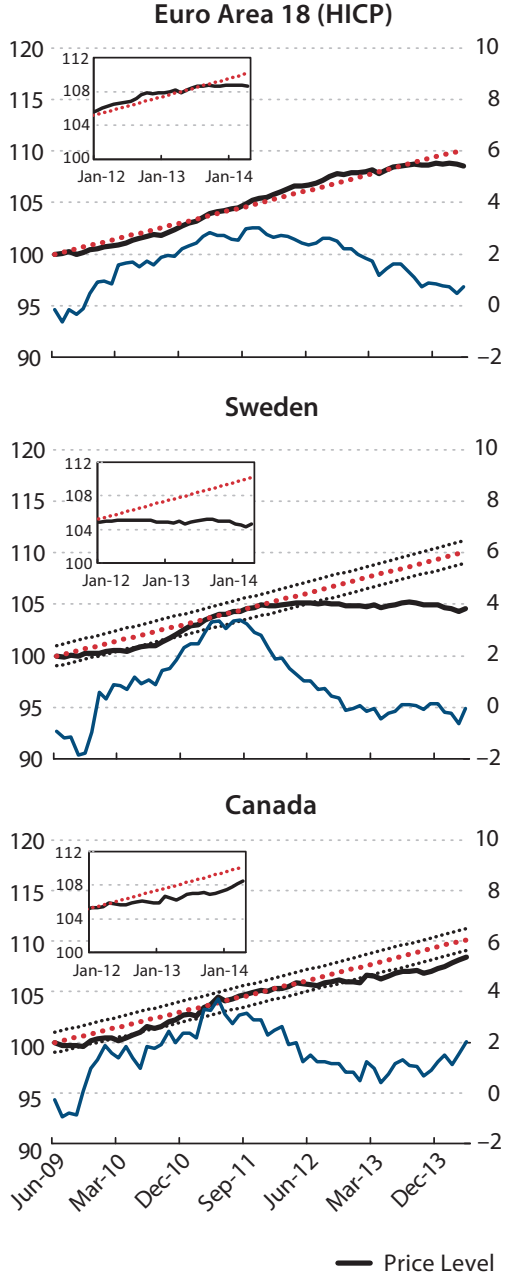

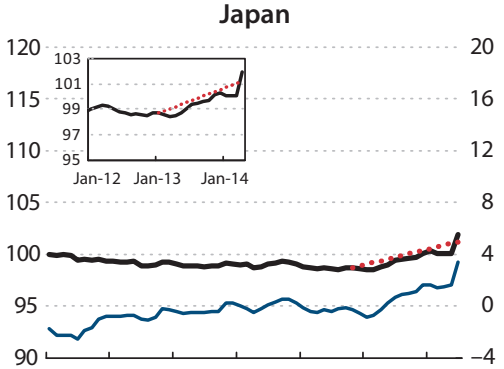

Switzerland
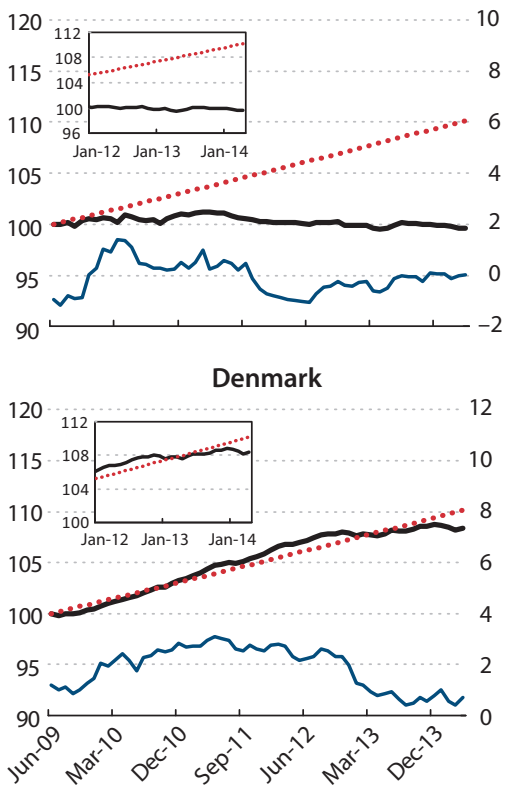

... Price Level Consistent with the Target
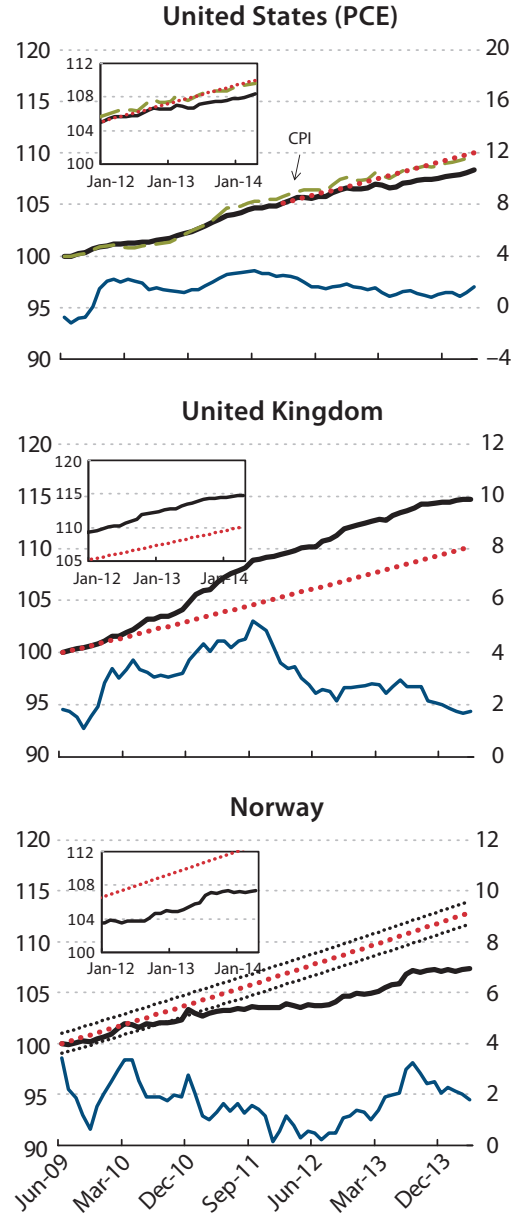

- Inflation Rate

NOTE: The inset charts are from January 2012 to February 2014; the $y$-axis scale is the same as the main chart.

SOURCE: Haver Analytics.

events that deviate from the forecast, but the change would still be consistent with the policy rule. In the second case, the central bank may want to guide private sector expectations with a commitment to monetary policy action in case of future deviations from the underlying policy rule, essentially tying its own hands. In particular, the goal of forward guidance at the zero lower bound has been to make agents expect the interest rate to stay at zero (or at least remain low) as the economy recovers. If people believe this expectation and real rates rise in a recovery, then, according to the Fisher equation, there should be downward pressure on inflation as it adjusts to clear the bond market (Gallmeyer et al., 2007). 


\section{Contessi, De Pace, Li}

\section{"THE PERIL" STRIKES BACK}

With this succinct description of policy frameworks in mind, we now focus on the relationship between short-term rates and inflation rates. Figure 3 indicates that inflation has recently been low not only for the euro area and the United States, but also for all advanced economies; some commentators describe this environment as "lowflation," or creeping disinflation (see Moghadam, Teja, and Berkmen, 2014). Figures 4 and 5 are constructed similar to those in Bullard (2010), who pointed out the dangers of falling into a Japanese-style deflationary environment and advocated boosting quantitative easing $(\mathrm{QE})$ to avoid this scenario.

The vertical axes on Figures 4 and 5 represent short-term rates as reported by the Organisation for Economic Co-operation and Development (OECD), and the horizontal axes represent inflation as described in the labels. The most recent short-term rates (as of June 2014) are listed in Table 1. In Figure 4, we use the individual-country inflation measure of headline inflation (for most countries, the monthly year-over-year CPI). In Figure 5, we use the yearover-year core inflation using the OECD measure of core inflation. The thicker vertical bar identifies the inflation target at 2 percent for all countries (except Norway, which is 2.5 percent), acknowledging that this is an approximation because of the exceptions discussed above.

We arbitrarily identify four periods: (i) 2002:01-2008:09 (the initial data point in Bullard, 2010 , corresponding to the beginning of the recovery from the 2001 recession through Lehman Brothers' collapse in September 2008); (ii) 2008:10-2009:06 (the period between the collapse of Lehman Brothers/beginning of the U.S. zero lower bound and the end of the U.S. recession); (iii) 2009:07-2012:11 (the recovery through the beginning of "Abenomics"-the set of new policies of Japanese Prime Minister Shinzo Abe); (iv) 2012:12-end of series (Abenomics).

Considering the nine countries in the same panel shows the following:

- In the period between the end of the 2001 U.S. recession and the collapse of Lehman Brothers that marks the beginning of the zero-lower-bound period in the United States, all countries were essentially circling around target. This is particularly evident considering the core measure of inflation.

- In the post-Lehman Brothers period through the end of the U.S. 2007-09 recession, all countries experienced falling inflation (sometimes with brief deflation) and quickly falling short-term rates.

- The period corresponding to the U.S. recovery witnessed a return to positive inflation circling around 2 percent for all countries but Switzerland (close to zero) and the United Kingdom (close to 3 percent).

- The months since the beginning of Abenomics were characterized by almost-zero lower bound rates and falling inflation. In some countries, rates were still positive but in others they were already negative (Sweden and Switzerland). In all countries but Japan, headline inflation had trended downward, but most recent data (second quarter of 2014) show an upward movement.

A comparison between Figures 4 and 5 shows a similar pattern emerging when only core inflation (the OECD measure, comparable across countries) is considered. While this could 


\section{Figure 4}

\section{International Comparison of the Relationship between Short-Term Rates and Inflation Rate (2002:01-2014:06)}
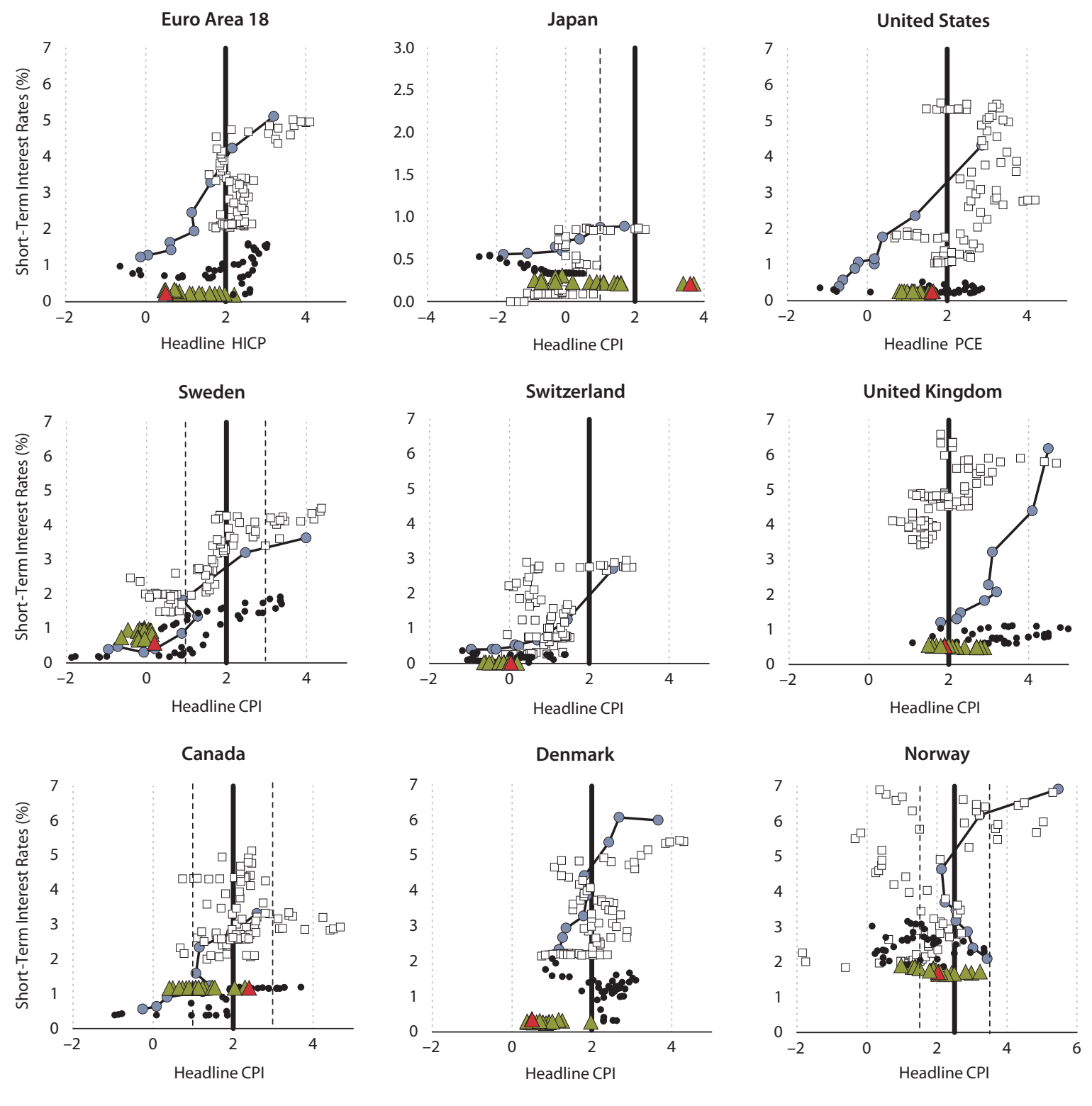

NOTE: Short-term rates are defined by the OECD and vary across countries. The thick vertical bars indicate the inflation target; in some cases it is the upper bound and in some cases the dashed bars indicate the target ranges. Japan targeted inflation at 1 percent until January 2013, but the bar in Japan's chart indicates the new 2 percent inflation target. The dates on which countries started adopting inflation targets are February 1991 (Canada), January 1993 (Sweden), January 1999 (euro area), January 2000 (Switzerland), March 2001 (Norway), December 2003 (United Kingdom), January 2012 (United States), and January 2013 (Japan). Denmark targets the exchange rate with the euro area.

SOURCE: Authors' calculations based on OECD statistics. 


\section{Figure 5}

\section{International Comparison of the Relationship between Short-Term Rates and the OECD Measure of Core Inflation (2002:01-2014:06)}
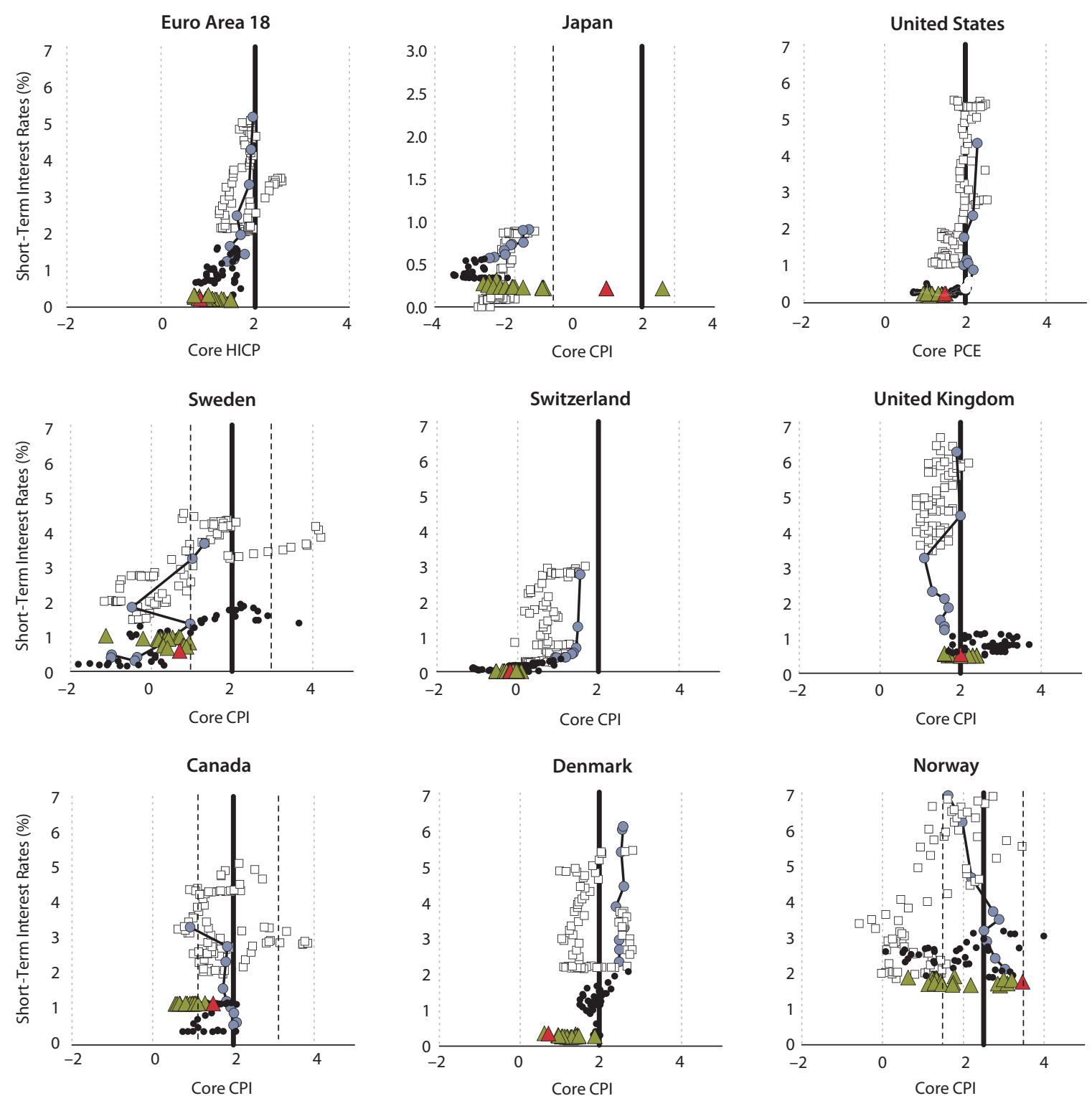

$\square$ 2002:01-Lehman — - Lehman-End of U.S. Recession End of U.S. Recession-2012:12

$\Delta$ Abenomics $\quad \Delta$ Last Observation

NOTE: Short-term rates are defined by the OECD and vary across countries. The thick vertical bars indicate the inflation target; in some cases it is the upper bound and in some cases the dashed bars indicate the target ranges. Japan targeted inflation at 1 percent until January 2013, but the bar in Japan's chart indicates the new 2 percent inflation target. The dates on which countries started adopting inflation targets are February 1991 (Canada), January 1993 (Sweden), January 1999 (euro area), January 2000 (Switzerland), March 2001 (Norway), December 2003 (United Kingdom), January 2012 (United States), and January 2013 (Japan). Denmark targets the exchange rate with the euro area.

SOURCE: Authors' calculations based on OECD statistics. 
be considered soft evidence that the downward trend in headline inflation is not driven solely by food and oil shocks, there is no hard evidence countering this claim.

If all countries were entered into an "advanced economies" group, the plot would show a picture very similar to that of advanced economies today, as Bullard (2010) has shown for the United States up to 2010. Bullard's analysis was an application of the model developed by Benhabib, Schmitt-Grohé, and Uribe (2001). Based on the Fisher relation and a nonlinear Taylor rule, Benhabib, Schmitt-Grohé, and Uribe identify two steady states in the economy: the "targeted" steady state (with positive interest rates and inflation) and the "unintended" steady state (with interest rates close to zero and deflation). When an active Taylor-type rule combines with the zero-lower-bound nominal interest rates, the economy may get locked into the unintended steady state, similar to Japanese-style deflation. Bullard (2010) then emphasizes that (i) the "extended period" language introduced by the Federal Open Market Committee (FOMC) and some of the post-crisis forward guidance language guidance may be increasing the probability of a Japanese-style outcome for the United States but, at the same time, (ii) the QE program offers the best tool to avoid such an outcome. More recently, formal and structured models have been developed to study the so-called creeping disinflation, particularly in Piazza (2014) and Armenter (2014).

\section{WHY SUCH LOW INFLATION IN SO MANY COUNTRIES?}

Various combinations of three arguments could explain the low inflation recently observed: (i) global shocks and composition effects, (ii) economic slack, and (iii) changing inflation expectations. In this section, we informally examine these explanations and examine them within the larger literature on inflation.

\section{Global Shocks}

An established literature estimates the role of global elements in determining domestic inflation. ${ }^{4}$ The basic argument is that global factors pass through domestic inflation rates, perhaps at different degrees across countries, so that inflation rates can be decomposed into global components, a regional component, and a domestic component. This argument is typically made using factor models that show the growing relevance of global factors in explaining domestic inflation rates over the years. Regarding the recent low inflation rates, some commentators have argued they may be due to the effect of a commodity glut, particularly oil, destined to continue because of structural changes in the world market, particularly growing capacity in the oil industry.

As noted in January 2014 by ECB President Mario Draghi (2014a), it is important to consider the comovement of different components of inflation rates (at both the geographic and industry levels) when attempting to evaluate the likelihood of a deflation scenario:

When we define deflation as a broad-based, self-fulfilling, self-feeding fall in prices, we do not see that in the euro area. Even when we look at individual countries we may actually see negative inflation rates in one or two countries, but then we should also ask how much of this is due to 
the necessary rebalancing of an economy that had lost competitiveness and had gone into a financial and budgetary crisis? And how much of it is due to actual true deflation? So, by and large, we do not see deflation in the Japanese sense of the 1990s.

Therefore, the role of global and domestic shocks can be intuitively observed by considering the dynamics of the noncore component of the inflation rate (food and energy) as well as in individual sectors. Limiting the discussion to the United States, Martin (2013) shows that falling prices in 2013 originated mostly in services (i.e., health care and housing), which are heavily influenced by policy intervention. A similar point was recently made by Sandra Pianalto (2014), then-President of the Federal Reserve Bank of Cleveland, who said that "a bout of sustained low inflation" is due to "two main sources: slow economic growth, which has put very little upward pressure on prices and wages; and special, temporary forces that have held back some prices, such as the deceleration of medical care costs." While this observation does not explain the downward trend of inflation in several advanced economies, it raises the possibility that different country-specific factors may be playing an important role in explaining low inflation in each, at the same time that global prices have been dormant.

To investigate the role of various types of goods and services in inflation, in Figure 6 we describe the dynamic behavior of inflation between 2012 and 2014 for three countries. The figure shows the contributions of inflation components to headline CPI inflation rates in the United States, the euro area, and Japan in June and December 2013 and January 2014. We choose these three months to focus on short-run movements. The size of each circle in the figure indicates the weight or relative importance of each component to the inflation rates. For example, food and beverages account for about 15 percent of the items in the goods and services basket for the United States, while housing accounts for about 41 percent (the weight in the personal chain-type expenditure price index inflation rate is about half of that). The center of a circle represents the respective $(x, y)$ point of a certain category. The $y$-axis represents the inflation contributions of each component to total CPI or the Harmonised Index of Consumer Prices (HICP) inflation rates. For example, in the United States, the inflation component for housing contributed about half of the total 2.08 percent CPI inflation rate in June 2014. The $x$-axis represents the percentage-point change of inflation rates from the previous year, $\pi_{i, t}-\pi_{i, t-1}$, where $i$ is the component of inflation index and $t=$ June 2013, December 2013, and June 2014. For example, for the circle representing food and beverages, the value on the $x$-axis is the year-over-year inflation rate only for these goods in June 2014 minus the yearover-year inflation rates for them in June 2013; if the inflation rate of food and beverages is falling between June 2013 and June 2014, then the circles will be in one of the left quadrants.

The United States experienced low inflation in 2013 and the beginning of 2014 but once it reached 1 to 1.5 percent, it stopped falling and began to move closer to 2 percent after April 2014. As shown in Figure 6, all components except housing are clustered in the top-left corner around zero in December 2013, indicating a slight decrease in each component's inflation rate from a year earlier, and thus the CPI inflation rate decreased as well to 1.5 percent. Recent U.S. CPI inflation rates are slowly moving up: The June 2014 CPI inflation rate reached 2.07 percent. Figure 6 shows that the circles are moving toward the top-right corner but are still 


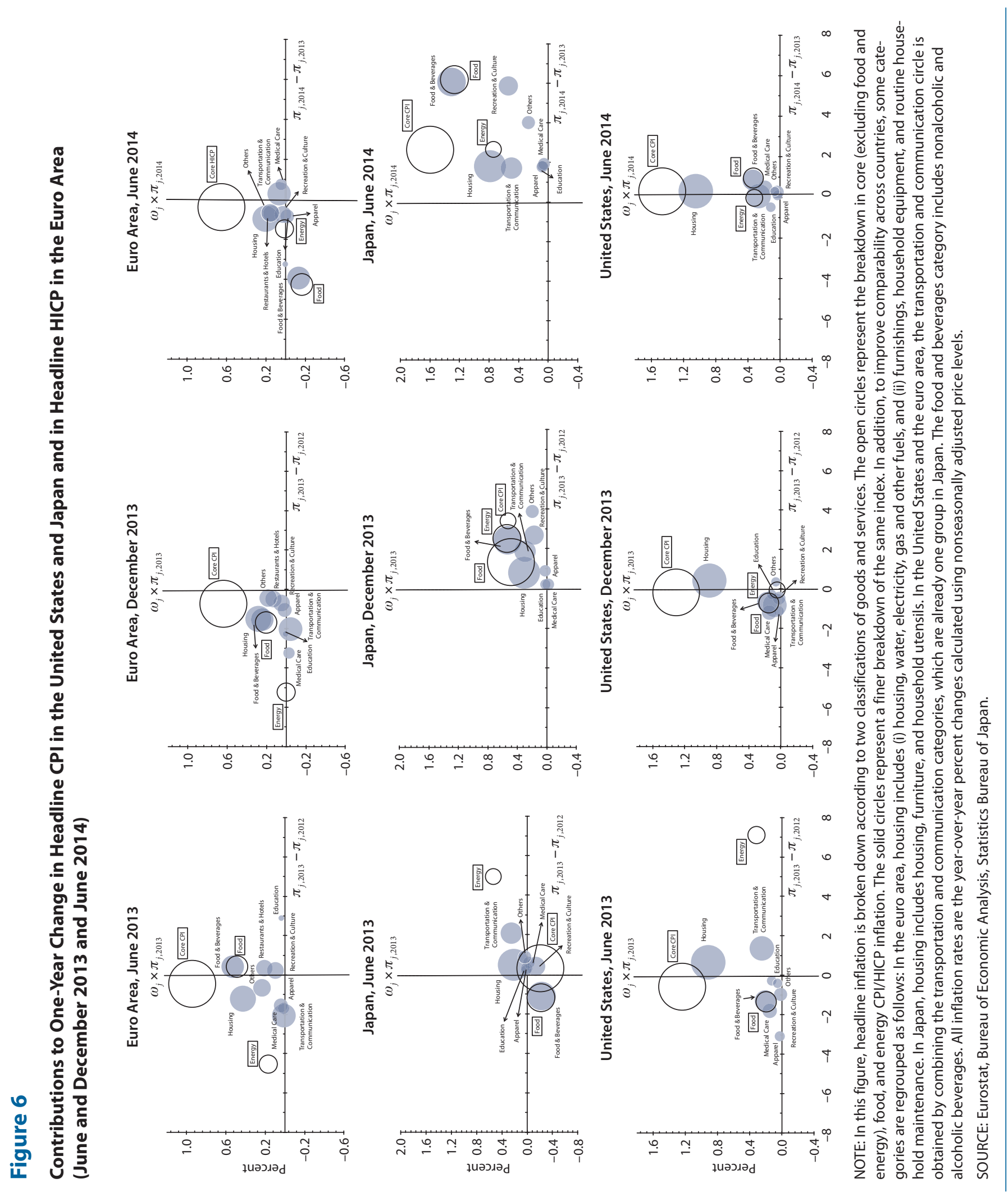




\section{Contessi, De Pace, Li}

very close to the vertical line, which indicates that the upward trend is moderate. In the euro area, however, the majority of the circles move downward and toward the left, indicating a downward trend in the HICP inflation rate between June 2013 and June 2014.

Japan shows a completely different picture with most circles in the top-right quadrant (see Figure 6). In December 2013 there was a small upward trend in each component, which resulted in a 1.61 percent CPI inflation rate. The movement became much larger in June 2014, resulting in a 3.41 percent CPI inflation rate. If we plotted the same panel for early 2013, most of the circles for Japan would be in the bottom-left quadrant instead. Because most of the circles are in the right quadrants in the panel, there is a very visible shift associated with Abenomicsnamely, that prices are growing across the categories of goods and services.

What do we make of these breakdowns? The first message is that while these economies have experienced somewhat persistent inflation below or close to 2 percent, the underlying trends appear quite different and low inflation rates in the three areas may have different explanations or the timing of creeping disinflation may be different. The euro area is facing the most serious threat of creeping disinflation, while the United States and Japan are experiencing either stable or mildly increasing prices across a wide spectrum of goods and services. This interpretation is reinforced by the most recent figures on U.S. inflation showing a noticeable increase in June 2014, relative to the previous months. Second, several studies have shown a growing global component to domestic inflation derived from food and energy prices (noncore items). However, this global component is contributing to domestic inflation in the three areas in different ways. Imagine there was a large global shock (due to, say, military tension) that caused a large increase in oil prices. Then the circle corresponding to energy would likely be in the upper-right quadrant for all three areas because energy inflation would be growing and its impact on total inflation would be increasing. However, energy and food prices have not behaved in the same way in the three areas: Energy prices are increasing in Japan but decreasing in the euro area (see "Energy" in Figure 6). Also, food prices are rising rapidly in Japan, are mildly crescent in the United States, but are decreasing in the euro area (see "Food" in Figure 6). These different directions suggest that the current inflation behavior, particularly in the United States, the euro area, and Japan, may be responding more to domestic conditions because global shocks have been dormant. ${ }^{5}$ Clearly, a more structured analysis is needed to study the effect of global shocks. ${ }^{6}$

Here, to gauge the importance of global factors, we rely on an approach used in Ciccarelli and Mojon (2010). They estimate a dynamic factor model for 20 OECD countries and show that a simple average of headline inflation across countries proxies the first factor reasonably well. Similar factor models are estimated in Macklem (2014) and the Bank for International Settlements (2014, Chap. 3).

In practice, we decompose domestic inflation rates for the nine countries $\left(\pi_{1 t}, \ldots, \pi_{9 t}\right)$ as follows:

$$
\left[\begin{array}{c}
\pi_{1 t} \\
\cdots \\
\pi_{9 t}
\end{array}\right]=\left[\begin{array}{c}
\Lambda_{1} \\
\ldots \\
\Lambda_{9}
\end{array}\right] f_{t}+\left[\begin{array}{c}
\varepsilon_{1 t} \\
\cdots \\
\varepsilon_{9 t}
\end{array}\right] .
$$


The vector $\Lambda$ captures the effect of a common factor $f_{t}$ to which each country $n$ responds differently through a factor loading $\Lambda_{n}$, with $n=1,2, \ldots, 9$. The last term, $\varepsilon_{n t}$, refers to the idiosyncratic shocks whose effects remain local. We assume orthogonality between the factor and the idiosyncratic component, as well as normality of the idiosyncratic term. ${ }^{7}$

We estimate a one-factor model for the monthly data on the sample beginning in 2002. The share of variance explained by the first factor is 50.85 percent. $^{8}$

In Figure 7, the time series of the first factor is then plotted along with the individual country inflation rate and the simple unweighted average of inflation rates across the nine countries. It is clear that there is a high correlation between the nine countries' simple average and the first factor extracted from our monthly data. More interestingly, there is a generally high correlation between the global factor and the domestic inflation rates (see Figure 7). In addition, in Figure 8, we show that the global factor comoves quite clearly with food and energy price indexes from the IMF. Particularly noteworthy is the very visible deviation of the Japanese inflation rate from global factors in the past 18 months.

The past few months are also interesting in light of the fact that commodity prices lead the global factor, and this leads domestic inflation over the entire sample. If the stable commodity prices have inhibited inflation, then inflationary pressures may mount if and when commodity prices increase.

While this analysis is significant to understanding headline inflation drivers and makes the global shock argument appear to be an important ingredient of any lowflation narrative, it is difficult to explain the observed low core inflation unless we assume a high degree of passthrough from noncore prices to core inflation. Therefore, we now examine two other explanations, the first of which can be tied to global factors.

\section{Economic Slack and Output Gaps}

The second explanation we consider is the role of economic slack and large output gaps (a measure-albeit problematic-of economic slack) following the Great Recession (see Ball, 2014). ${ }^{9}$ These arguments are related to the so-called mystery of "missing disinflation" studied in more detail in Ball and Mazumder (2011), Coibion and Gorodnichenko (2013), Gordon (2013), and others. The "missing deflation puzzle" was clearly explained by Williams (2010, p. 8) as follows:

The surprise [about inflation] is that it's fallen so little, given the depth and duration of the recent downturn. Based on the experience of past severe recessions, I would have expected inflation to fall by twice as much as it has.

The role of large output gaps can be discussed within the framework of the so-called New Keynesian Phillips curve. In such a framework, current inflation, $\pi_{t}$, is positively related to inflation expectations, $E\left(\pi_{t}\right)$, and negatively related to the current output gap, as measured by the level of cyclical unemployment, $\left(\tilde{u}_{t}\right), \pi_{t}=E\left(\pi_{t}\right)-\kappa \tilde{u}_{t}$, where $\kappa$ is a parameter referred to as the slope of the Phillips curve. This stylized representation is a simplification of the "true" process driving inflation rates and a useful tool to help assess the role of the potential drivers of inflation over time. 


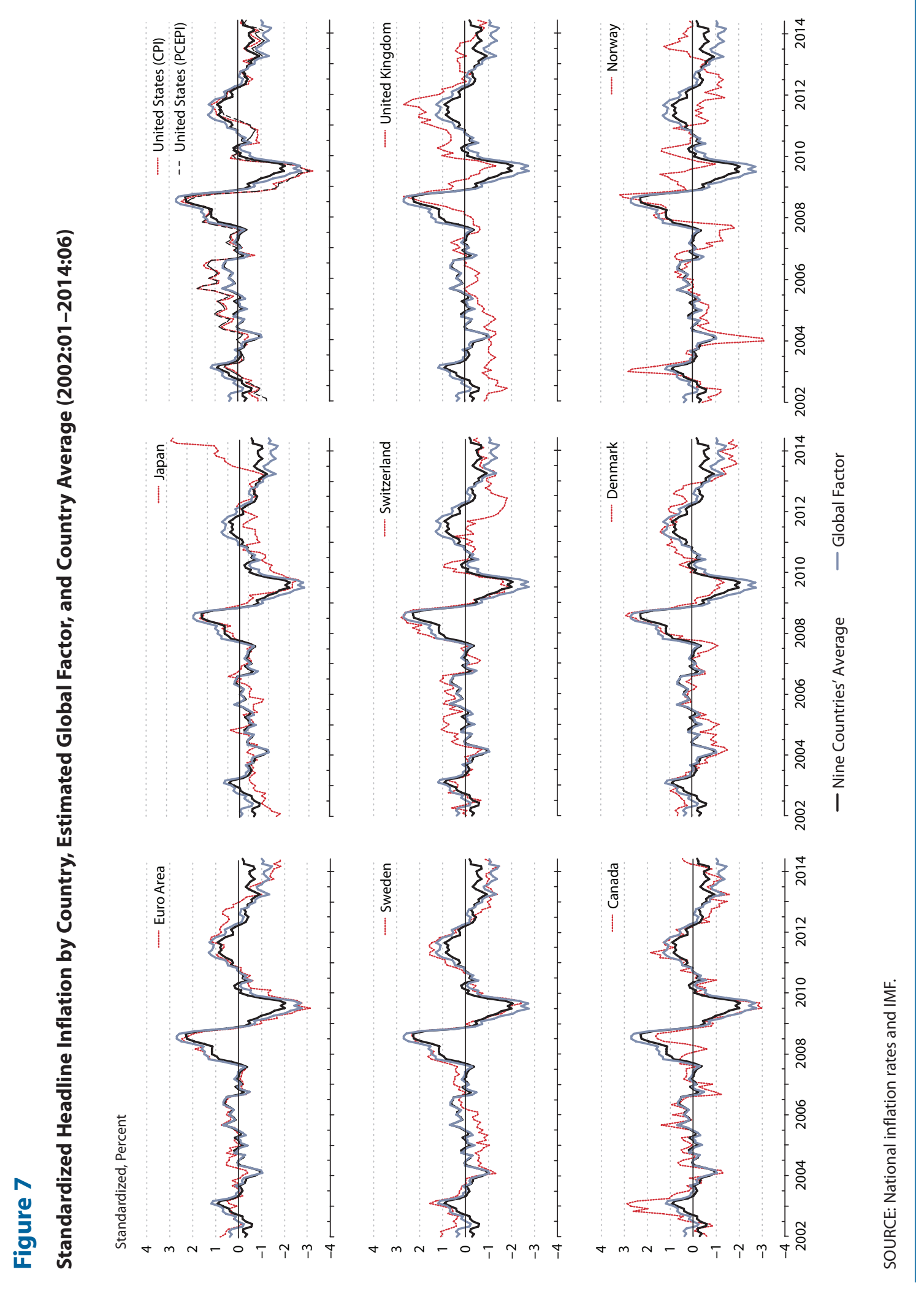




\section{Figure 8}

\section{Global Factor Versus Global Energy and Food Price Inflation (Demeaned and Normalized by Standard Deviation; 2002:01-2014:06)}

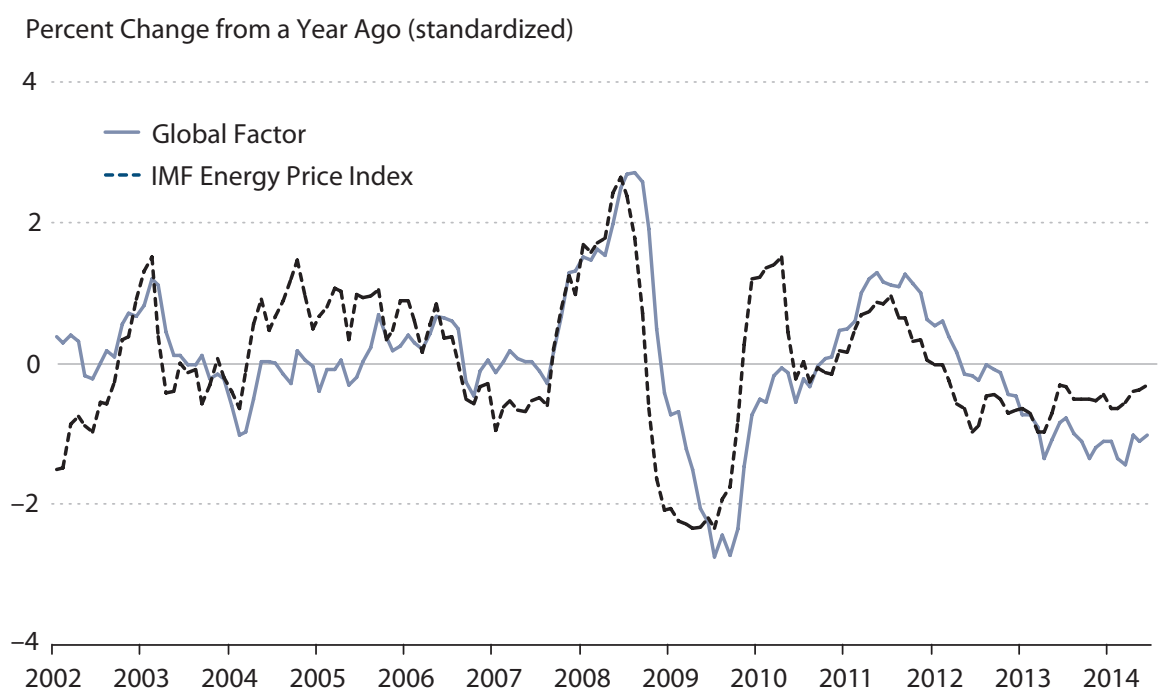

Percent Change from a Year Ago (standardized)

4

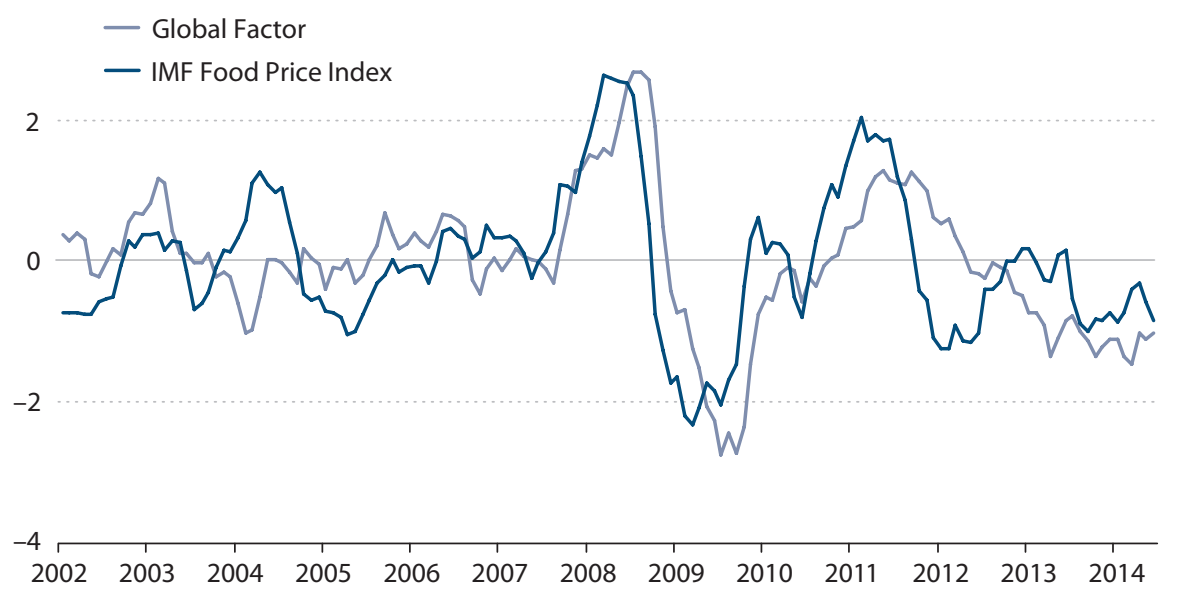

NOTE: The price indexes series are standardized as $(\pi-\mu) / \sigma . \pi$ is the sample mean, and $\sigma$ is the sample standard deviation.

SOURCE: IMF and authors' calculations. 


\section{Contessi, De Pace, Li}

In the above context, the fall in inflation during the Great Recession could have been limited for three possible reasons: (i) Increased unemployment might have been structural and thus there might have been only a small change in cyclical unemployment. (ii) More-credible central banks might have made inflation expectations more stable (see the next section). (iii) The Phillips curve might have become flatter than in the past ( $\kappa$ might have decreased over the years), and thus the sensitivity of inflation to changes in cyclical unemployment (i.e., the responsiveness of inflation to economic slack) might now be less significant.

Some international evidence regarding the relationship between output and inflation is available in Simon, Matheson, and Sandri (2013, Chap. 3). They find that (i) a considerable share of the increase in unemployment during the Great Recession was cyclical, not structural; (ii) inflation expectations have become more anchored around targets during the past two decades; and (iii) the relationship between economic slack and changes in inflation has gone from positive (falling inflation with more negative output gaps) to essentially null between the late 1970s/early 1980s and the period after 1995.

While empirically evaluating the changed relationship between measures of economic slack and inflation is beyond the scope of this article, we look informally at this relationship over the past few years. In Figure 9, on the horizontal axes we plot output gap measures provided by the OECD and constructed using a methodology that is consistent across countries. The figure shows plots for the 2009-11 and the 2012-14 periods (data for 2014 are projections). According to these measures, in the nine countries considered, the simple average output gap fell from 3.58 percent in 2007 to -3.36 percent in 2009 and then bounced back to -1.84 percent in 2013. By 2002-13 standards, these output gaps are not small (the average output gap for the 2002-13 is -0.14). On the vertical axes we plot the change in inflation between any two years using both actual inflation in two subsequent periods (top panel) and inflation minus inflation expectations (bottom panel). We measured inflation expectations for each year using the CPI/HICP from the OECD Economic Outlook-Annual Projections for OECD countries dataset for June of the previous year. We pool all nine countries together. For inflation expectations, the relationship between output gaps and changes in inflation is negative (larger output gaps are associated with growing inflation) during both the 2009-11 and 2012-14 periods. Generally, a clear relationship with changes in inflation similar to historical evidence does not emerge when simply eyeballing the panel, consistent with more formal analysis reported in Simon, Matheson, and Sandri (2013, Chap. 3).

Recent research by Borio and Filardo (2007), as well as the Bank for International Settlements (2014, Chap. 3), has pointed out that Phillips curve analyses incorporating measures of global economic slack can resurrect the trade-off between economic slack and inflation at the domestic level. Measures of global economic slack can be added to commodity prices as external factors affecting domestic inflation rates, which could be positively correlated with latent factors such as the one estimated in the previous subsection.

Nevertheless, in addition to the weakening of the relationship between inflation and output gaps, it should be noted that a narrative relating these two variables during the recent recovery would need to account for the facts that (i) inflation was higher a few years ago when output gaps were larger (by any estimate) and (ii) it fell below target in many countries as output gaps likely shrank with the progress of the recovery. 


\section{Figure 9}

\section{Annual Output Gaps and Changes in Inflation in the Nine Countries (2009-11 and 2011-14)}
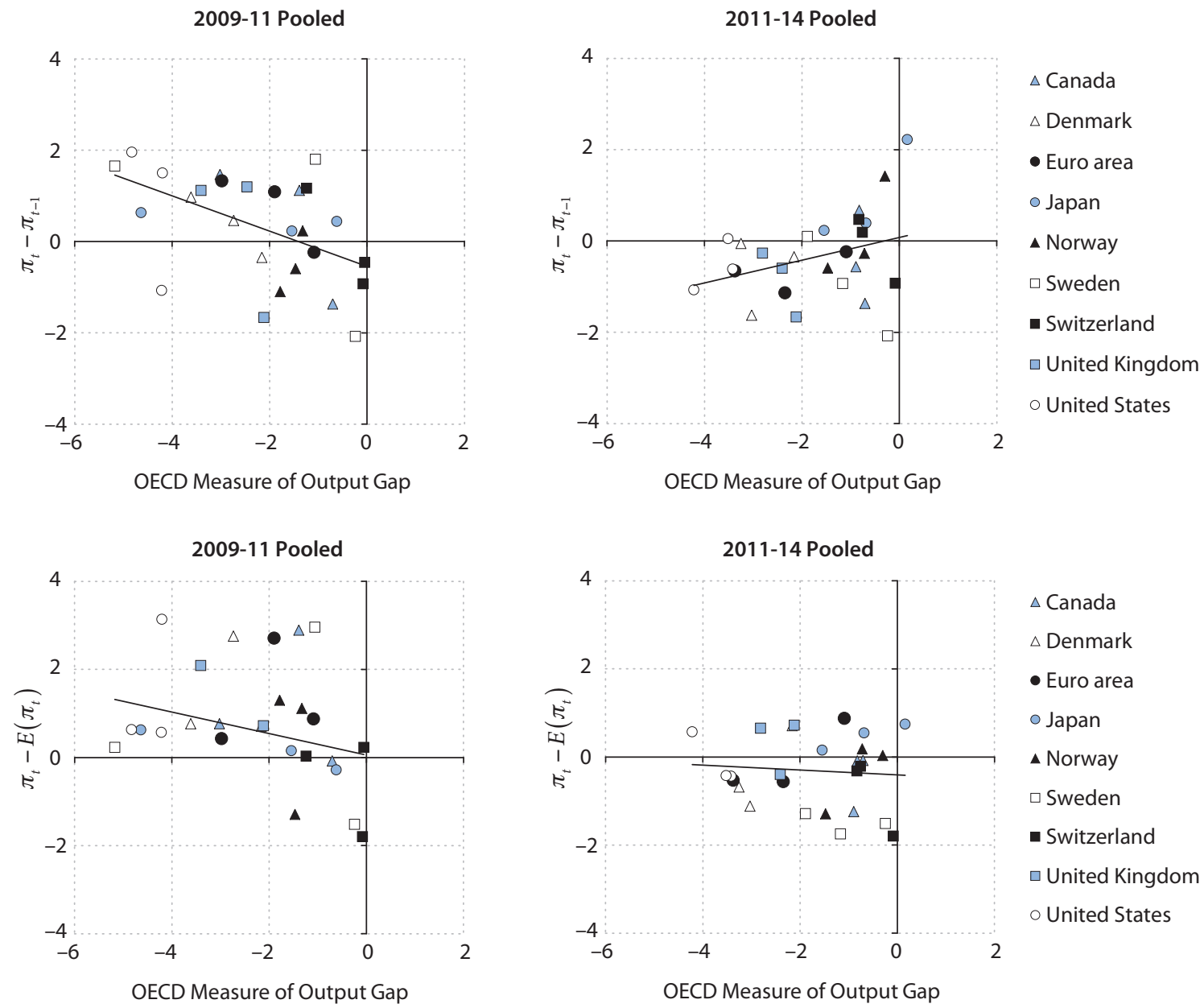

NOTE: The inflation rates are all the year-over-year rate of change in headline CPI, expect the euro area uses the headline HICP (top panel). In the bottom panel, we replace lagged inflation with the expectation of inflation for the following year as published in the Economic Outlook-Annual Projections for OECD countries.

SOURCE: OECD; 2014 figures are projections.

\section{Changes in Inflation Expectations}

Finally, we consider another potentially important driver of low inflation that is also connected to Phillips curve analyses: inflation expectations. Several central banks have successfully anchored inflation expectations close to their targets since late 1980. Large deviations in inflation expectations from target levels would signal that agents may readjust their expectations, in this case downward, and then build-in the lower expected inflation in price and wage contracts. 


\section{Contessi, De Pace, Li}

Figures 10 and 11 show the recent behavior of two possible measures of inflation expectation-monthly vintages of the inflation forecast by the FocusEconomics Consensus Forecast and market-based inflation expectations inferred from breakeven rates-for the countries for which this measure can be reconstructed. It should be recognized that there is consensus that advanced economies have kept short- and medium-run inflation expectations anchored to their targets and that short-run fluctuations away from the target are not unusual.

Figure 10 shows quite clearly that expected inflation for 2014 has progressively fallen for the euro area, Sweden, Switzerland, and Denmark; mildly decreased for the United States, United Kingdom, and Canada; and remained stable for Norway. A similar pattern is evident in the breakeven-rate-based measure of expectations for the countries for which rates are available. Quite impressively, inflation expectations are trending upward for all measures available for Japan. ${ }^{10}$

A potentially more inflammatory explanation is that inflation expectations have changed and/or LSAP/QE is deflationary (see Williamson's New Monetarist blog on November 27, 2013; Andolfatto's MacroMania blog on December 1, 2013; and the counterargument made in Krugman's Conscience of a Liberal blog on November 29, 2013). The Economist's version of this hypothesis is that "prolonged" LSAP/QE is effectively a signal that the central bank is unwilling to commit to higher inflation and, therefore, QE reinforces expectations that economic activity will run below potential and demand shocks will not be completely offset (see London, 2013). Such conjecture would not explain why countries with no history of LSAP/QE are also experiencing low inflation (for example, Canada and Norway), unless the possibility of large cross-country spillovers of inflation is also considered, as examined in the next section.

\section{THE CROSS-COUNTRY CORRELATION OF INFLATION}

The last step of our analysis is to consider the cross-sectional correlation of inflation. Thanks to Wang and Wen (2007), we know that inflation has been more correlated across countries than real output growth at business cycle frequencies. How did this correlation change after the financial crisis? Their article considers quarterly data from 18 economies for the January 1977 to April 1998 period. We reconsider the issue using a shorter but updated period; we use the months and quarters since the beginning of 2002 and the same group of countries. Several combinations of measures of inflation could be considered. We chose monthly headline CPI inflation and industrial production (IP) growth; in an unreported analysis we obtain similar correlations using the cyclical component of the IP index and the price level after using a Christiano-Fitzgerald band-pass filter. Figure 12 shows a scattergram of correlations between pairs of countries for IP growth (horizontal axis) and CPI inflation (vertical axis) for the 2002:01-2008:8 period on the left side and the 2008:09-2014:04 period on the right side.

The first observation, also highlighted by Imbs (2010), is that cross-country correlations of IP growth have grown since the beginning of the financial crisis, which is clear from the rightward movement of the correlations on the horizontal axis: Output growth measured by the IP index growth rate has increased visibly. For inflation, the correlation of the inflation 


\section{Figure 10}

Inflation Expectations for 2014 by Country and Vintage (2010:06-2014:06)
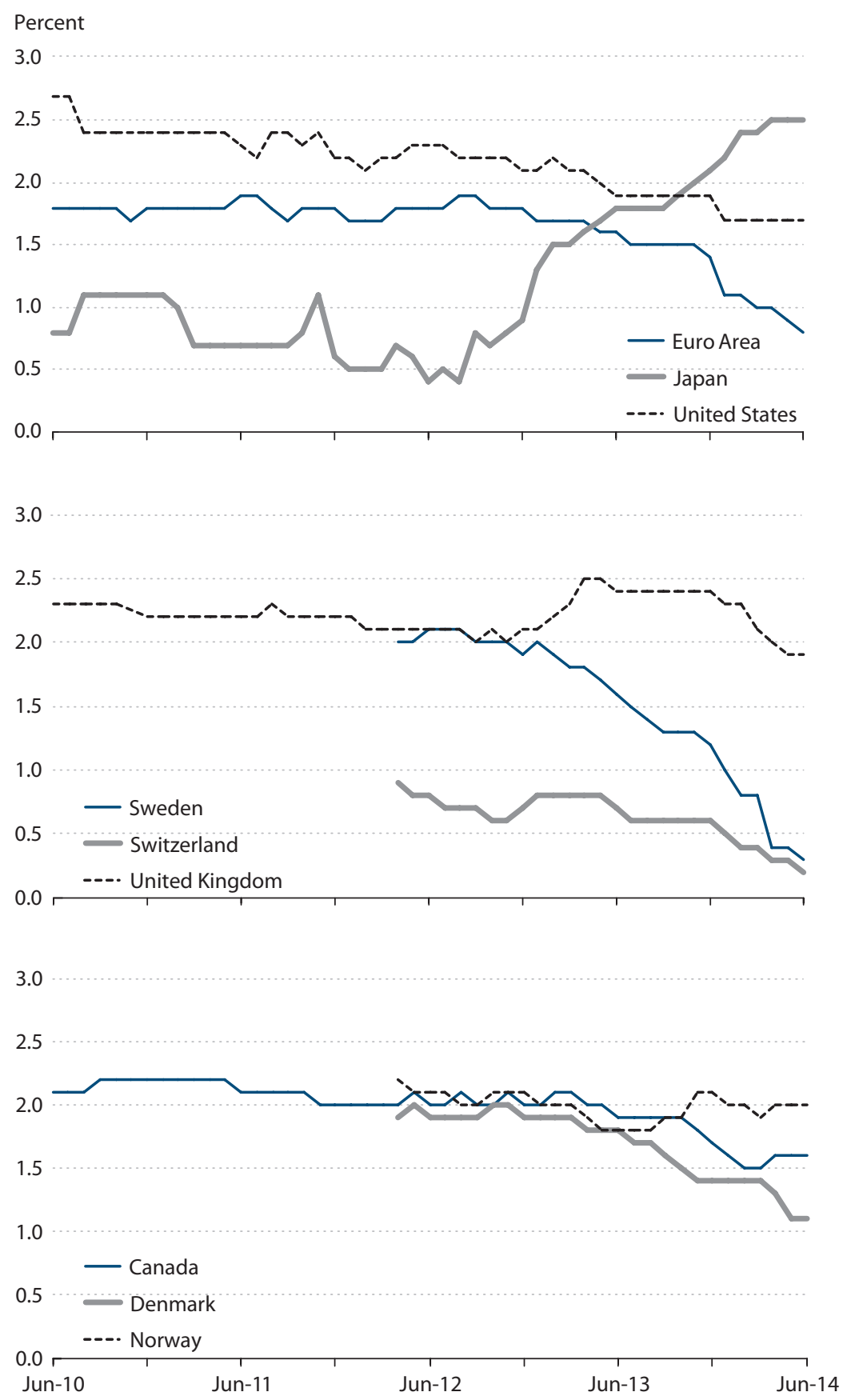

NOTE: Each data point represents the inflation forecast for 2014 that is made at that point in time. SOURCE: FocusEconomics Consensus Forecast. 


\section{Contessi, De Pace, Li}

\section{Figure 11}

Short-Term Inflation Expectations by Country: Breakeven Rates (2009:06-2014:06)

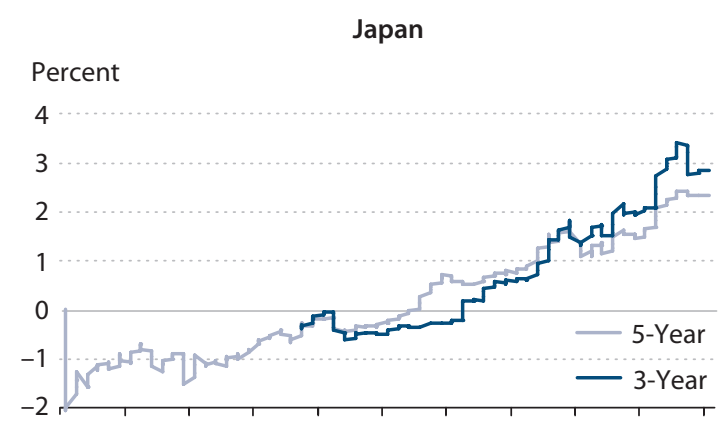

Sweden

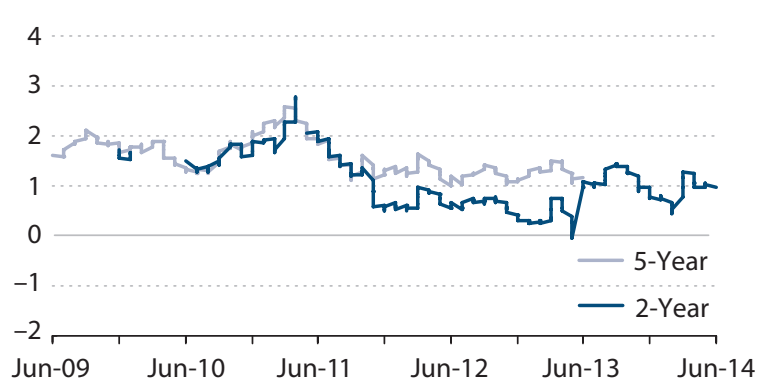

United States

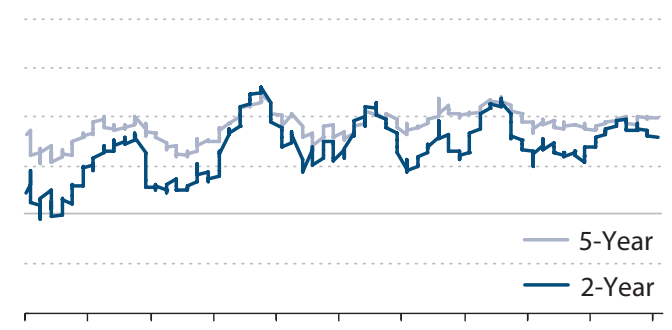

United Kingdom, Canada

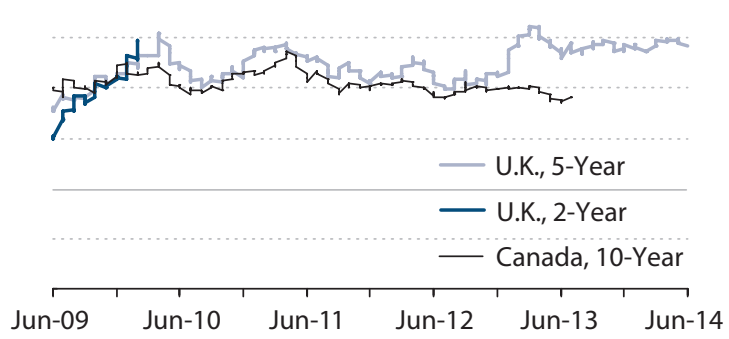

SOURCE: Data from Bloomberg.

rate has not changed much compared with the increase in the correlation of the IP index growth: The cross-country average correlation of IP growth rates has moved from 0.28 to $0.82(+0.54)$ while inflation correlation has increased from 0.67 to 0.73 on average $(+0.06)$. This shows that inflation is no longer more correlated across countries than output. It is also noteworthy that the average standard deviation of inflation has increased from 0.20 to 0.28 .

Figure 12 also allows comparison of similar correlations with respect to nominal shortterm rates: Short-term rate correlations increased visibly. The cross-country averages increased from 0.67 to 0.73 , and they are now less correlated than output, unlike in the pre-crisis years.

What do these changes indicate? With small cross-country spillovers of shocks, Taylor rules, and domestic no-arbitrage conditions, Henriksen, Kydland, and Ŝstek (2013) generate a ranking of correlations similar to the pre-crisis scattergram. They argue that small international spillovers and similar policy reaction functions in various countries can persistently generate highly correlated inflation rates. One possibility is that low inflation produced in large economies for domestic reasons may be spilling over to neighboring small open economies through a similar mechanism. Thus low inflation may be observed in large economies because of domestic reasons ${ }^{11}$ as explained above, but falling inflation in small open economies may be due to monetary policy reaction functions that include a component connecting them to 
Contessi, De Pace, Li

\section{Figure 12}

Cross-Country Correlation of IP Growth, Headline CPI Inflation, and Short-Term Rates (2002:01-2014:04)
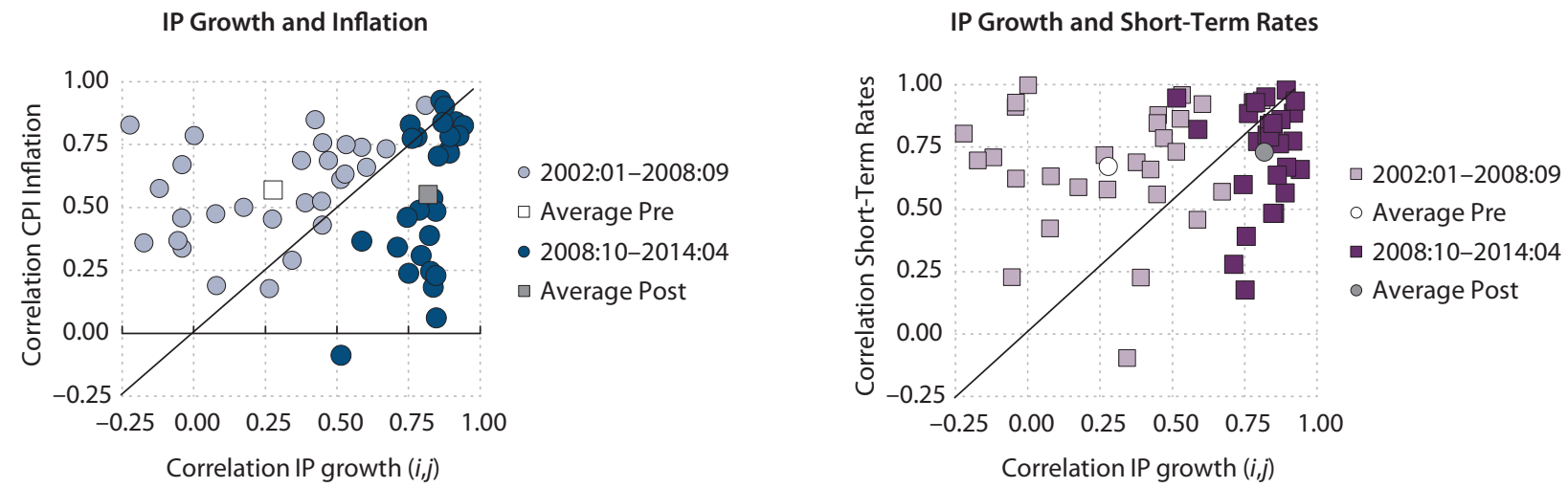

\section{Cross-Country Covariance and Standard Deviation of Headline CPI Inflation and Short-Term Interest Rates in Two Periods}
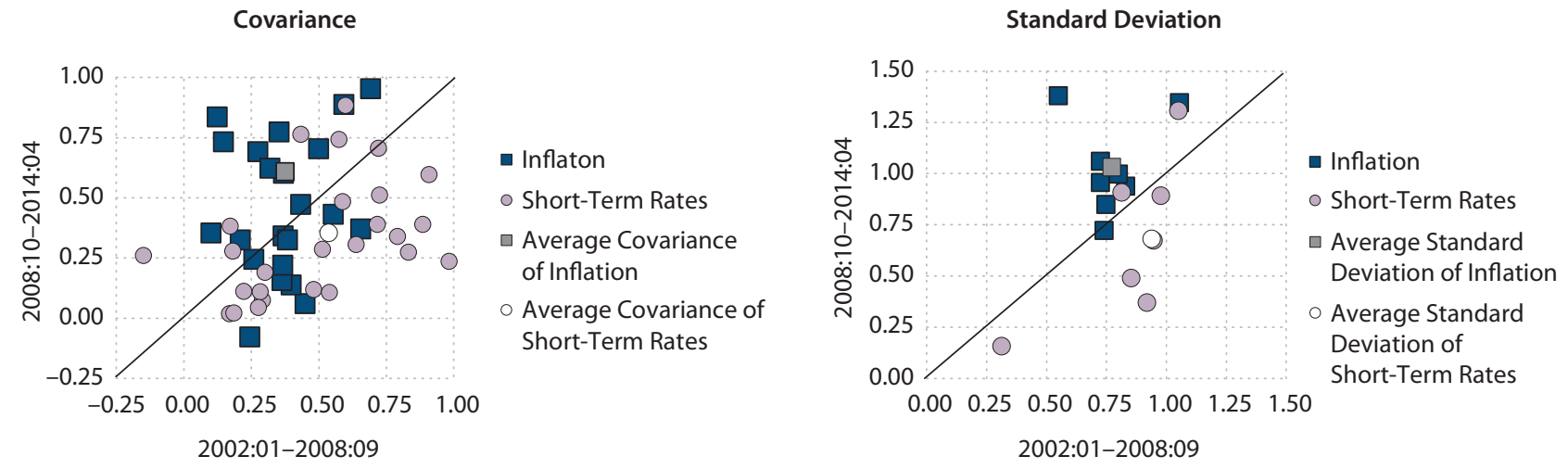

SOURCE: OECD and authors' calculations.

their larger partners and neighbors. This is clearly evident for Canada with respect to the United States and even more so for Denmark with respect to the European Union, as Denmark specifically targets the exchange rate with the euro, making this link even more explicit. For the crisis period, it appears that the real spillovers captured by the cross-country correlations of IP growth rates have been much more significant than any monetary spillover measured by cross-country inflation rates and short-term interest rates correlations. This would suggest that global factors for real measures of output might have become more relevant in the postcrisis period.

The bottom panels in Figure 12 also point to the source of these changes in correlations: While inflation rates correlations have changed little, the panels show that this is the outcome of an increase in both the covariances and the standard deviations of inflation rates, which 


\section{Contessi, De Pace, Li}

net out to produce a mild increase in correlations. As for short-term rates, both covariances and standard deviations have fallen on average, with the net effect of a mild increase in correlations, as the former fell less than the latter.

This analysis of bilateral relationships warrants further research on the role of global spillovers in the analysis of global inflation after the Great Financial Crisis.

\section{CONCLUSION}

In this article, we collect data for nine advanced economies and document the following facts about the behavior of inflation during the 2002-14 period. First, we show that the relationship between inflation rates and short-term rates displays similar changes across advanced economies that have or have not implemented forms of central bank programs designed to increase the size of their balance sheets (such as LSAPs/QE). Second, recent data indicate that headline and core inflation are below the inflation targets of individual countries. We discuss various explanations for this trend in the post-financial crisis world-global factors and composition effects, economic slack and output gaps, changing inflation expectations-showing there is some heterogeneity across countries, particularly large economies. Finally, we show that while output has become even more synchronized across countries since 2008 , the crosscountry correlation of inflation is no longer higher than the cross-country correlation of output.

Our main conclusion is that there are striking similarities across advanced economies regarding the behavior of inflation after the Great Financial Crisis, perhaps mirroring the global nature of the recent crisis and recovery, as well as broadly similar monetary policy responses. Under the surface, however, there are also important international differences that warrant further research. While the evidence provided here is informal and simply suggestive, very recent low inflation rates across countries are likely the combination of economic slack in the global economy (particularly in the euro area) and the stability of commodity prices. 


\section{NOTES}

1 The object of analysis is the period of the Great Financial Crisis and the subsequent recovery. We use the pre-crisis years as a term of comparison. We acknowledge this is a limited time period. In more technical ongoing research, we use a longer period and a larger number of countries. Preliminary results from this larger dataset suggest that our results concerning the factor model and comovement are robust to the extension.

2 See the following references for the "Target" descriptions: Euro Area 18 (ECB, undated); Japan (Bank of Japan, 2013a); United States (FOMC, 2013); Sweden (Sveriges Riksbank, undated); Switzerland (Swiss National Bank, 2011); United Kingdom (Bank of England, undated); Canada (Bank of Canada, undated); Denmark (Rasmussen, 2013); Norway (Norges Bank, 2003).

3 The Bank of Japan (2013b) set the "price stability goal in the medium to long term" in a positive range of 2 percent or lower in terms of the year-over-year rate of change in the CPI and set a goal at 1 percent. On January 22, 2013, the Bank of Japan replaced a "goal" with a "target" and set that target at 2 percent in terms of the year-over-year rate of change in the $\mathrm{CPI}$.

4 Examples of this research include work by Ciccarelli and Mojon (2010), Mumtaz and Surico (2012), Neely and Rapach (2011), and Monacelli and Sala (2009).

5 See Macklem (2014) for a more formal analysis of global factors in domestic inflation.

6 One such analysis is contained in a speech by the former senior deputy governor of the Bank of Canada, Tiff Macklem (2014). In this speech, Macklem refers to a staff factor model analysis of Canadian inflation and reaches conclusions similar to our informal analysis here-that is, global factors play a role in explaining low inflation in Canada, but other factors are also at play.

7 As in Ciccarelli and Mojon (2010), the factors are estimated using static principal component methods described in Stock and Watson (2003), with standardized data.

8 This share is lower than Ciccarelli and Mojon's (2010) results, based on quarterly data beginning in 1960.

9 Simon, Matheson, and Sandri's (2013) Chap. 3 in the 2013 World Economic Outlook provides one of the most recent analyses of the relationship between output gap and inflation rates in the United States and OECD countries. We rely in part on this analysis for this section.

${ }^{10}$ Coibion and Gorodnichenko (2013) make the interesting point that inflation expectations by consumers are more volatile and responsive to energy and other global prices than inflation expectations of professional forecasters. Because the evidence from countries with both consumer and firm-level inflation expectations surveys shows that these are closer than consumer and professional forecasters' expectations, consumer-survey-based expectations should be used in Phillips curve analyses. Once this is done for the United States, the Phillips curve can be "resurrected."

${ }^{11}$ For example, slow-growing health care costs in the United States as suggested by Pianalto (2014), more intense competition in the distribution sectors in Canada as suggested by Macklem (2014), or large recessions in the euro area countries as suggested by Draghi (2014b).

\section{REFERENCES}

Andolfatto, David. "Is QE Lowering the Rate of Inflation?" MacroMania (blog), December 1, 2013; http://andolfatto.blogspot.com/2013/12/is-qe-lowering-rate-of-inflation.html.

Armenter, Roc. "The Perils of Nominal Targets." Federal Reserve Bank of Philadelphia Working Paper, No. 14-2/R, February 2014; http://philadelphiafed.org/research-and-data/publications/working-papers/2014/wp14-2R.pdf.

Ball, Laurence M. “Long-Term Damage from the Great Recession in OECD Countries.” NBER Working Paper No. 20185, National Bureau of Economic Research, May 2014; http://www.nber.org/papers/w20185.pdf.

Ball, Laurence and Mazumder, Sandeep. "Inflation Dynamics and the Great Recession." Brookings Papers on Economic Activity, Spring 2011, 42(1), pp. 337-81. 


\section{Contessi, De Pace, Li}

Bank for International Settlements. "Growth and Inflation: Drivers and Prospects." 84th BIS Annual Report: 1 April 2013-31 March 2014. Chap. 3. Basel: BIS, 2014, pp. 41-63; http://www.bis.org/publ/arpdf/ar2014e.pdf.

Bank of Canada. "Inflation." Undated; http://www.bankofcanada.ca/core-functions/monetary-policy/inflation/ (accessed August 27, 2014).

Bank of England. "Monetary Policy Framework." Undated; http://www.bankofengland.co.uk/monetarypolicy/Pages/framework/framework.aspx (accessed August 27, 2014).

Bank of Japan. "'Price Stability Target' of 2 Percent and 'Quantitative and Qualitative Monetary Easing.'” January 2013a; https://www.boj.or.jp/en/mopo/outline/qqe.htm/ (accessed August 27, 2014).

Bank of Japan. "The 'Price Stability Target' under the Framework for the Conduct of Monetary Policy." January 22 2013b; https://www.boj.or.jp/en/announcements/release_2013/k130122b.pdf.

Benhabib, Jess; Schmitt-Grohé, Stephanie and Uribe, Martín. "The Perils of Taylor Rules." Journal of Economic Theory, January 2001, 96(1-2), pp. 40-69.

Board of Governors of the Federal Reserve System. "How Does Forward Guidance about the Federal Reserve's Target for the Federal Funds Rate Support the Economic Recovery?" Current FAQs, 2014; http://www.federalreserve.gov/faqs/money_19277.htm.

Borio, Claudio E.V. and Filardo, Andrew. "Globalisation and Inflation: New Cross-Country Evidence on the Global Determinants of domestic Inflation." BIS Working Papers No. 227, Bank for International Settlements, May 2007; http://www.bis.org/publ/work227.pdf.

Bullard, James. "Seven Faces of "The 'Peril.' Federal Reserve Bank of St. Louis Review, September/October 2010, 92(5), pp. 339-52; http://research.stlouisfed.org/publications/review/10/09/Bullard.pdf.

Ciccarelli, Matteo and Mojon, Benoît. "Global Inflation." Review of Economics and Statistics, August 2010, 92(3), pp. 524-535.

Coibion, Olivier and Gorodnichenko, Yuriy. "Is the Phillips Curve Alive and Well After All? Inflation Expectations and the Missing Disinflation." NBER Working Paper No. 19598, National Bureau of Economic Research, October 2013; http://www.nber.org/papers/w19598.pdf.

Contessi, Silvio and Li, Li. “Forward Guidance 101A: A Roadmap of the U.S. Experience." Federal Reserve Bank of St. Louis Economic Synopses, No. 25, September 10, 2013a; http://research.stlouisfed.org/publications/es/13/ES_25_2013-09-10.pdf.

Contessi, Silvio and Li, Li. “Forward Guidance 101B: A Roadmap of the International Experience." Federal Reserve Bank of St. Louis Economic Synopses, No. 28, October 16, 2013b; http://research.stlouisfed.org/publications/es/13/ES_28_2013-10-16.pdf.

Draghi, Mario. “Introductory Statement to the Press Conference (with Q\&A)." Frankfurt, Germany, January 9, 2014a; http://www.ecb.europa.eu/press/pressconf/2014/html/is140109.en.html.

Draghi, Mario. "A Consistent Strategy for a Sustained Recovery." Presented at Sciences Po, Paris, France, March 25, 2014b; http://www.ecb.europa.eu/press/key/date/2014/html/sp140325.en.html.

European Central Bank. "The Definition of Price Stability." Undated; https://www.ecb.europa.eu/mopo/strategy/pricestab/html/index.en.html (accessed August 27, 2014).

Fawley, Brett and Neely, Christopher. "The Evolution of Federal Reserve Policy and the Impact of Monetary Policy Surprises on Asset Prices." Federal Reserve Bank of St. Louis Review, First Quarter 2014, 96(1), pp. 73-109.

Federal Open Market Committee. "Why Does the Federal Reserve Aim for 2 Percent Inflation Over Time?" Current FAQs, September 26, 2013; http://www.federalreserve.gov/faqs/economy_14400.htm (accessed August 27, 2014).

Gallmeyer, Michael F.; Hollifield, Burton; Palomino, Francisco J. and Zinin, Stanley E. "Arbitrage-Free Bond Pricing with Dynamic Macroeconomic Models." Federal Reserve Bank of St. Louis Review, July/August 2007, 89(4), pp. 305-326; http://research.stlouisfed.org/publications/review/07/07/Gallmeyer.pdf.

Gordon, Robert J. "The Phillips Curve Is Alive and Well: Inflation and the NAIRU During the Slow Recovery." NBER Working Paper No. 19390, National Bureau of Economic Research, August 2013;

http://www.nber.org/papers/w19390. 
Hammond, Gill. "State of the Art of Inflation Targeting - 2012." Bank of England, Centre for Central Banking Studies Handbook, No. 29, February 2012;

http://www.bankofengland.co.uk/education/Documents/ccbs/handbooks/pdf/ccbshb29.pdf.

Hatcher, Michael C. and Minford, Patrick. "Stabilization Policy, Rational Expectations and Price-Level versus Inflation Targeting: A Survey." Working Paper No. E2013/14, Cardiff Economics Working Papers, December 2013; http://business.cardiff.ac.uk/sites/default/files/E2013_14.pdf.

Henriksen, Espen; Kydland, Finn E. and Ŝustek, Roman. "Globally Correlated Nominal Fluctuations." Journal of Monetary Economics, September 2013, 60(6), pp. 613-31.

Imbs, Jean. "The First Global Recession in Decades." IMF Economic Review, December 2010, 58(2), pp. 327-54.

Krugman, Paul. "On the Importance of Little Arrows (Wonkish)." Conscience of a Liberal (blog), New York Times, November 29, 2013; http://krugman.blogs.nytimes.com/2013/11/29/on-the-importance-of-little-arrowswonkish/?_php=true\&_type=blogs\&_r=0.

London, R.A. “Is QE Deflationary?" Free Exchange (blog), Economist, December 4, 2013; http://www.economist.com/blogs/freeexchange/2013/12/monetary-policy.

Macklem, Tiff. "Flexible Inflation Targeting and 'Good' and 'Bad' Disinflation." Presented at the John Molson School of Business, Concordia University, Montreal, Canada, February 7, 2014; http://www.bankofcanada.ca/2014/02/flexible-inflation-targeting-good-bad-disinflation/.

Martin, Fernando M. "U.S. Inflation and Its Components." Federal Reserve Bank of St. Louis Economic Synopses, 2013, No. 33, December 6, 2013; http://research.stlouisfed.org/publications/es/13/ES_33_2013-12-06.pdf.

Moghadam, Reza; Teja, Ranjit and Berkmen, Pelin. “Euro Area-'Deflation' Versus 'Lowflation."' iMFdirect (blog), March 4, 2014; http://blog-imfdirect.imf.org/2014/03/04/euro-area-deflation-versus-lowflation/.

Monacelli, Tommaso and Sala, Luca. "The International Dimension of Inflation: Evidence from Disaggregated Consumer Price Data." Journal of Money, Credit, and Banking, February 2009, 41(s1), pp. 101-20.

Mumtaz, Haroon and Surico, Paolo. "Evolving International Inflation Dynamics: World and Country-Specific Factors." Journal of the European Economic Association, August 2012, 10(4), pp. 716-34.

Neely, Christopher and Rapach, David. "International Movements in Inflation Rates and Country Characteristics." Journal of International Money and Finance, November 2011, 30(7), pp. 1471-90.

Norges Bank. "Regulation of Monetary Policy." Section 1, May 23, 2003; http://www.norges-bank.no/en/about/ Mandate-and-core-responsibilities/Legislation/Regulation-on-Monetary-Policy/ (accessed August 28, 2014).

Pianalto, Sandra. "President's Message: Keeping Inflation in Check," in 2013 Annual Report: Why Inflation Is Very Low, and Why It Matters. Federal Reserve Bank of Cleveland, 2014, pp. 4-5; http://www.clevelandfed.org/about_us/annual_report/2013/.

Piazza, Roberto. “Liquidity Traps and Self-Defeating Policies." Working paper, Banca d'Italia, August 7, 2014; http://robertopiazza.net/liquidity_traps.pdf.

Rasmussen, Arne Lohmann. "Denmark Conducts a Fixed-Exchange Rate Policy," in Negative Deposit Rates: The Danish Experience. November 2013, p. 4; http://danskeanalyse.danskebank.dk/abo/NegativeratesinDK November2013/\$file/Negative_rates_in_DK_November_2013.pdf (accessed August 27, 2014).

Simon, John; Matheson, Troy and Sandri, Damiano. “The Dog That Didn't Bark: Has Inflation Been Muzzled or Was It Just Sleeping?" in World Economic Outlook, April 2013: Hopes, Realities, Risks. Chap. 3. Washington, DC: International Monetary Fund, 2013; pp. 79-95; http://www.imf.org/external/pubs/ft/weo/2013/01/pdf/text.pdf.

Stock, James H. and Watson, Mark W. "Has the Business Cycle Changed and Why?" in Mark Gertler and Kenneth Rogoff, eds., NBER Macroeconomics Annual 2002. Volume 17. Chap. 4. Cambridge, MA: MIT Press, 2003, pp. 159-225.

Sveriges Riksbank. "The Inflation Target." Undated; http://www.riksbank.se/en/Monetary-policy/Inflation/Adoption-of-the-inflation-target/ (accessed August 27, 2014).

Swiss National Bank. "103rd Annual Report 2010." February 2011; http://www.snb.ch/en/mmr/reference/annrep_2010_komplett/source/annrep_2010_komplett.en.pdf (accessed August 27, 2014). 


\section{Contessi, De Pace, Li}

Thornton, Daniel L. "QE: Is There a Portfolio Balance Effect?" Federal Reserve Bank of St. Louis Review, First Quarter 2014, 96(1), pp. 55-72; http://research.stlouisfed.org/publications/review/2014/q1/thornton.pdf.

Wang, Pengfei and Wen, Yi. "Inflation Dynamics: A Cross-Country Investigation." Journal of Monetary Economics, October 2007, 54(7), pp. 2004-31.

Williams, John C. "Sailing into Headwinds: The Uncertain Outlook for the U.S. Economy." Presented at the Joint Meeting of the San Francisco and Salt Lake City Branch Boards of Directors. Closing Luncheon, Salt Lake City, UT, September 8, 2010; http://www.frbsf.org/economic-research/files/john_williams0908.pdf.

Williamson, Stephen. "Liquidity Premia and the Monetary Policy Trap." Stephen Williamson: New Monetarist Economics (blog), November 27, 2013;

http://newmonetarism.blogspot.ca/2013/11/liquidity-premia-and-monetary-policy.html. 